\title{
In the Absence of Security:
}

\section{A Memoir}

\section{CHRIS BELL}

|

Chris Bell teaches American cultural studies at the University of Bielsko-Biala in Poland. He also conducts research in memory studies at Auschwitz. Soon, he will move to the UK to commence a $P h D$ program examining AIDS through the lens of memory studies.

If I should die tonight/Though it be far before my time/ I won't die blue/'Cause I've known you.

- Marvin Gaye

I met Billy Vance in September. We saw each other three more times that fall. He died the following March. Of course I had no way of knowing this would be the sequence of events on the occasion of our meeting. We met at a reception given partially in his honor after he was named as one of the new university fellowship recipients. The reception was attended by representatives from the university administration, faculty members, and current fellows like myself. We convened in the Great Room of the university's Alumni Center. I attended the affair with Gwenyth, another graduate student. After chugging my second glass of Merlot, I felt particularly witty and charming; thus, I left Gwenyth, inserting myself on the fringe of a social circle consisting of the Provost and a few of his minions. Shortly thereafter, Dr. Provost assumed his position at the podium and introduced the new fellows. As the list of names was read aloud, I scanned the room, looking for something (read: someone) of interest.

"And from the Department of English, Billy Vance, Ridgel Fellow," boomed Dr. Provost's stentorian voice. 
I was immediately brought back to the occasion at hand. English was my field; and a Ridgel Fellow? Since I was already acquainted with the other English fellows, I wanted to know which individual had received the highly-coveted Ridgel Fellowship, named after the first black student to earn a degree from the university.

To my right, a hand waved, or perhaps it beckoned, I don't know. In any case, my attention was instantly riveted to this individual. My concern had little to do with his elf-like stature, nor the lessthan-casual way he was clad in jeans, in direct defiance of the dress code for functions such as this. I gazed at this person, this Billy Vance, Ridgel Fellow, because he was ... well ... white. At least he certainly looked so from my vantage point. Judging from the necks craning throughout the Great Room and the expressions of curiosity coloring everyone's faces, I was not alone in my thinking.

And what did Billy Vance do as the smattering of polite applause welcomed him into the fold of the university and we all stared at him, wondering if he had lied on his fellowship application? Perhaps he had stated he was an ethnic minority, a prerequisite for the fellowship, when he apparently was anything but? What did he do, this individual who stood slightly apart from the rest of us, next to the plate-glass window, his face bleached of distress? He smiled. Holding his half-full glass of Chardonnay with enviable ease, Billy Vance smiled, his face utterly aglow.

As Dr. Provost continued reading through the litany of names, I snuck glances at Billy Vance, and each time he positively beamed.

"I'm going to meet Billy Vance," I announced to Gwenyth.

Dr. Provost had completed the reading of the names. A great swell of applause thundered through the Great Room. The new fellows looked pleased with themselves. The veteran fellows looked at their watches, thinking of the piles of work waiting from them in their respective residences. The faculty and administrators looked with consternation at the rapidly diminishing collection of wine bottles atop the serving banquette.

"I don't know him. But he's in The Department," said Gwenyth, referring to the English Department not as "our" department, but as "the" department, a practice everyone in The Department adopted.

"I'm not familiar with him either, and it's time to change that." 
Without further word, Gwenyth and I walked across the lushlypiled carpet, past the leisurely dripping ice sculptures and the various social groupings, finally settling ourselves in front of the theretofore unheard of Billy Vance.

He looked at us and-I swear- even his eyes were smiling. My attention, however, was not focused on his eyes. Instead, I gawked at his mouth; more specifically, what was inside of it-a set of severely decaying teeth, in need of immediate attention. Evidently undaunted by this dental nightmare, he continued smiling, as if waiting for Da Vinci to rise from his extended slumber, snatch down the aging portrait of that winsome jeune fille, and replace it with the more arresting countenance of Billy Vance, Ridgel Fellow.

"Hi."

The word sprang from his lips. I glanced at Gwenyth to gauge which of us should speak.

"Hello," she ventured. "We heard you're in The Department. So are we. My name is Gwenyth and this is Chris."

Effortlessly increasing the wattage in his effervescent smile, Billy Vance extended an assured hand to each of us.

"It's a pleasure meeting you both," he declared.

For the next half hour, until the conclusion of the reception, I remained in Billy Vance's company. Realizing, as he most likely did as well, that I was in the presence of another gay man, I did the inevitable: I sized him up. The hair which hadn't seen a comb for weeks, maybe months; the alert, dancing blue eyes; that smile; the v-necked white T-shirt; the faded through wear, not by design, blue jeans; the Doc Marten boots. I was intrigued by the slow cadence of his voice as he explained that he had applied to The Department's graduate program because someone had told him his poetry was "pretty good."

When Gwenyth returned, stating that it was time to leave, I said to Billy Vance, "I've enjoyed chatting with you. I'm sure I'll see you around The Department."

"Okay. Hey, I'm going out tonight. Maybe I'll contact you," he stated, discreetly alluding to the local gay hotspot, Contacts.

"Hmm. Maybe I'll drop by if I finish grading papers."

As Gwenyth and I left the Great Room, I glanced back at him once more: the hair, the eyes, that smile. At that precise moment, I came to the realization that I was not attracted to Billy Vance. 
I didn't see him much in The Department. This was no surprise, as his focus was creative writing and mine was literature, meaning that we shared none of the same classes. He wrote, I was to learn later, poems that pulsated with the power of his reality, while I feigned interest in my course readings.

One night in early October, one month after we first met, I attended a meeting of the Gay and Lesbian Graduate Student Association (GLGSA). The group was planning the dance that would conclude the local community's celebration of National Coming Out Week. We had just dispensed with the lengthy distribution of duties when in walked Billy Vance, smiling. Penny, the chair of the GLGSA, informed him that the meeting was over, but we would appreciate his help at the dance. He said he would be glad to assist and, soon after, we adjourned.

I saw him next at the dance. He arrived about forty minutes after we had decorated, set up the DJ and refreshments, let the public in, and collected the money. It annoyed me that he had not been there to help. Moreover, he didn't bother apologizing for his tardiness by explaining that his previous engagement had kept him. No, he merely drifted in; clad in the same faded jeans, flashing the ubiquitous smile, and strolled past the cashier, without paying, to the dance floor.

After the dance, he conveniently disappeared while the GLGSA cleaned up. I quickly followed suit.

The last time I saw Billy Vance was on a brisk December morning when our paths crossed in front of the campus library. The conversation was brief, the typical banter of graduate students.

"How're your classes going?"

"Fine, yours?"

"Okay, but I'll be glad when the semester's over."

Shared laughter.

"Me, too!"

"Well," he said, without consulting a watch, "I have to go. I'll see you later, Chris."

"Yeah, I'll see you."

I never did. 


\section{iii}

Fast forward to the Ides of March, three months after the encounter outside of the library. Gwenyth and I were driving home and chatting. She described a new curricular idea for the class she was teaching. At one point, she abruptly changed the subject, asking if I had "heard about" Billy Vance.

"What about him?"

"He's HIV-positive. I hear he's really sick, really sick. I heard about it from..."

I tuned out as Gwenyth shared the name of the person she had learned the news from. I didn't expect her to understand how much this news impacted me, how overwhelming it was. Gwenyth didn't realize that, like many gay men, I measured my own vulnerability by the number of individuals I knew personally who were infected by The Virus, a number that, as a result of this conversation, had increased, from zero to one.

It wasn't until after Gwenyth had dropped me off at home that I realized she seemed much more affected by her pedagogical breakthrough than she was by Billy Vance's illness.

$*$

I don't remember where I was when Gwenyth relayed the news. I do know it was the very next week.

"Billy Vance died."

It wasn't as if she told me out of a sense of sorrow or loss. She just sort of mentioned it in passing.

*

Billy Vance's death wasn't the only one that distressed me that March. Two weeks before he died, my favorite hip-hop artist, the Notorious B.I.G., was murdered. I envied Biggie for the hypnotizing cadence of his delivery as well as his talent in turning the events of his reality into powerful, pulsating lyrics of brutality, pain, and wit. But that's another story. Or is it?

iv

Less than a week after Billy Vance's death, I walked into the graduate student teaching "office," an assortment of cubicles in the basement of the building where we stored our textbooks, graded papers, and convened office hours. I had decorated my cubicle with a variety of 
items: a pair of bumper stickers-"Feminism is the radical notion that women are people" and "Thelma and Louise Live"-a collection of library books, and a downloaded picture of Montgomery Clift, circa "A Place in the Sun." The office was deserted, save the cubicle directly across from mine that was occupied by Thurman, another graduate student in The Department. When I entered the office, Thurman was at his desk, his normally erect carriage leaning against one of the exposed pipes.

"What's wrong?" I asked.

"Oh, hi Chris," Thurman mumbled.

"What's wrong?" I repeated.

"I've just found out I have lupus. That's why I've been so fatigued lately."

"Oh, Thurman..."

"But that's not all. I went upstairs to talk to..." Thurman named The Department's Director of Graduate Studies (DGS). "I told him I needed to drop a class because I'm sick. When I said that..."

He paused.

"When I said, 'Dr. [DGS], I'm sick,' he stood up, backed away from me, and said 'Ohmygod! You don't have AIDS, do you?!'”

"What?!"

"He asked if I had AIDS. When I told him 'No,"”-indignation flashed in Thurman's eyes- "he said, 'Oh, well, as long as you don't have AIDS,' and sat back down. I had to get the hell away from him, so I came down here."

Before I could respond, indeed, before I could think of a response, Thurman stood up.

"Where are you going?"

"I have to go back to the hospital to meet with the doctor."

"Well, do you need anything? Do you want me to bring you dinner tonight?"

"You don't have to do that."

"Well, I'm going to call you later. Let me know what I can do." "Thanks."

As he left the office, the door clicked shut with a finality I had not heard before.

Alone in the office, I sat at my desk and grew pensive. Moments later, I leapt up and walked out of the office door. Marching upstairs, I headed towards the office of The Department's top gun, the Chair. 


$$
\text { * }
$$

When I entered the Chair's office, his assistant glanced up and smiled.

"Is he in?" I asked, nodding towards the closed door of the Chair's inner sanctum.

"He is, but he has a meeting with the Dean in ten minutes."

"This won't take long," I assured her. "And it can't wait."

The Chair soon ushered me into his office, making room for me to sit by removing a prodigious heap of books from one of the two chairs in front of his desk. It appeared to be the same pile of books, stacked in the same order, that had been there the last time I was in this office, months earlier. He sat opposite me and, after adopting his unctuous voice, asked what brought me to see him.

I relayed the story Thurman shared with me. When I arrived at Dr. [DGS]'s caustic "You don't have AIDS?!" inquiry, the Chair slumped back in his chair, closed his eyes, and shook his head.

"He didn't. Tell me he didn't."

"He's taking this harder than I expected," I thought to myself. Any feelings that I might have been out of line recounting this storywhich had nothing to do with me-had rapidly disappeared.

"It's true."

"Chris, let me tell you something." The Chair leaned towards me, his face assuming an expression of administrative gravitas. "Dr. [DGS] is a wonderful scholar. His publication record is superb and his student evaluations stellar. One trait he admittedly lacks, however, is tact. Sometimes he just opens his mouth and inserts his foot. Why, I remember the first time I met him ..."

While the Chair, chuckling good-naturedly, reminisced about this inaugural meeting, I pondered his already-spoken words. So the illustrious Dr. [DGS] - tenured, prize-winning professor-was a social moron. This individual - who possessed a trio of degrees from the Ivy League-lacked the social graces most of us are indoctrinated with early in life. Not only that, he had convinced others to excuse his venomous ejaculations and other insensitivities because ... well ... just because.

“... and so, I hope you'll forgive him for that lapse, Chris. He really can't help it."

The Chair offered his aw-shucks grin while I sat in stony silence. For the next few seconds, I gazed around the Chair's office at the 
disarray of dog-eared texts lining the bookshelves, the rubber plants barely clinging to life, the layer of dust cloaking his computer monitor.

"Nothing changes," I thought to myself. "I could come here for months, years, and nothing, least of all attitudes, would change."

Taking note of the Chair's failure to inquire about Thurman's health, I sensed my joie de combat rising. This nascent anger was quickly tempered, however, by a sense of reconciliation through understanding. Looking the Chair directly in the eye, I nodded. Then, rising to my feet, I thanked him and left.

I wandered back downstairs to the graduate student teaching office, which was now abuzz with a swarm of routine activity: copies of class handouts jamming the ancient copier, undergraduates beseeching their smirking graduate instructors for paper extensions, the staccato clanging of the pipes. Yet no one was talking about Billy Vance, and this despite the fact that his now-vacant cubicle was in the midst of the din.

Grabbing my backpack, I left the office and the building and walked, in the gloaming, towards the parking garage. As I slid into my car, I was unperturbed by my imminent absence from that afternoon's "Shakespeare's Women" seminar.

Driving out of the parking garage, I thought about Dr. [DGS]'s gratuitous expression of alarm and the unsatisfying meeting with the Chair. I considered The Department's collective silence about Billy Vance, how effectively he had been removed from the discourse. These thoughts led to my sense of an internal crossing-over, from unconsciousness to awareness. I surprised myself by voicing those feelings aloud. Stopped at a red light on Providence Road, the street separating the campus from the rest of the world, I said to myself, "I do not belong here."

The light changed. I crossed.

$\mathbf{v}$

The semester Billy Vance died coincided with the first time The Department offered a graduate seminar on teaching the Holocaust. I was not enrolled in this class; however, I was regularly apprised of the goings-on in the seminar by Gwenyth, who was. Many times throughout the semester, I wished I had enrolled in the Holocaust 
pedagogy class instead of the Victorian literature and Shakespeare seminars I had opted for. Hearing from Gwenyth the legacies passed down through generations, I wondered: What did the Jews, gypsies, and gays think and feel, knowing the "ordinary" individuals - their friends and neighbors-were aware of their plight and responded by denying what was happening, adhering to their daily routines, doing nothing? But that too is another story. It must be.

vi

It has now been almost two years since Billy Vance died. The events described here are as evocative to me in this moment as they were then. Because of Billy Vance, I have learned to pay closer attention to the ways that people come into and leave our lives and the ripples they leave behind. Regardless of the amount of time we share with them, these people arguably become a part of us, their lives intertwined with ours. We do not live in isolation. Each of us influences and affects the other whether we acknowledge this or not.

In retrospect, when I met Billy Vance, I told myself I was not attracted to him. Accordingly, I presumed this meant that he held no attraction for me, that there was nothing he could give me. I was wrong. Billy, in his death and its aftermath, transformed me. He brought me out of my stupor as far as realizing how AIDS is/not negotiated in our culture. Indeed, the fact that I have devoted my life to AIDS advocacy is a fact that I owe partially to Billy. It might sound egotistical, but I feel that his positioning in that space at that time was critical for my own development.

I think about Billy, I think about him often. Now that I know many others who are HIV-positive and who have died from AIDS; now that I have received a positive HIV diagnosis; now that I have left The Department without finishing my degree, I think of him.

When I think about Billy, I sometimes ask myself: Why didn't he tell me he was positive? Why didn't he tell me he was dying? Was it because he didn't trust me? Or maybe he didn't want people to know? Perhaps he didn't know himself? But surely ...

When I think about Billy, I think of the person I never knew, the person he might have been. I also think about the person that I 
was then and how I have changed since he died. (In that way, this memoir is as much mine as it is his.) But more often than not, I think about this:

The night I first met Billy in the Alumni Center's Great Room, we saw each other later at Contacts, the gay bar. Since it was a weeknight, the crowd was sparse, so the handful of us flirted with those we considered worthy, and ignored those we thought less of. A few moments before closing, the then-popular George Michael song "Fastlove" came blaring over the bar's sound system. As I made my way to the dance floor, another figure materialized from the smoky haze on the opposite side of the bar. When we reached our respective places on the deserted-except-for-us dance floor, we ignored one another. Our focus solely on our own gyrations, we studiously disregarded the eyes of the other patrons. Under the pulsating lights and stares, the other dancer grinned and free-flowed to the sounds he heard, while I moved to the infectious beat of "Fastlove," a song about one person's quest for casual sex, wherein the singer croons:

In the absence of security/

I made my way into the night/

Stupid Cupid keeps on calling mel

But I see nothing in his eyes.

When I think about Billy Vance, I remember the way he appeared at that moment, on the brink of summer's end-dancing and smiling, smiling and dancing, secure in his own inviolate world-frankly, the freest spirit I have ever met. 